\title{
School Lighting Measurements Campaign in Romania
}

\author{
Campanie pentru Iluminatul Şcolar în România
}

\section{Alexandru-Daniel Vlas ${ }^{1}$, Andy-Alexandru Balazs ${ }^{1}$, Andras Vernes ${ }^{1}$, Dorin $\mathrm{Beu}^{2}$, Mircea-Ion Buzdugan ${ }^{2}$}

${ }^{1}$ Technical University of Cluj-Napoca

Cluj-Napoca, Romania

E-mail:alex_vlas@yahoo.com,balazsandyalex@gmail.com,vernesandras@gmail.com

${ }^{2}$ Lighting Engineering Laboratory, Technical University of Cluj-Napoca

Cluj-Napoca, Romania

E-mail:_dorin.beu@rogbc.org,mircea.buzdugan@insta.utcluj.ro

DOI: $10.37789 /$ rjce.2022.13.1.13

\begin{abstract}
Lighting levels for educational buildings in Romania has evolved in time due to the development of various lighting technologies, from the incandescent to light emitting diodes. The measuring campaign found that the majority of the educational buildings are using fluorescent and LED light sources. Results showed that the majority of the college classrooms have a lower mean illuminance value (119lx-243lx) than the recommended level of the SR-EN 12464-1 of 300 lx. In case of classrooms for adult education (208.88 lx - $413.45 \mathrm{~lx}$ ), the illuminance levels are below the $500 \mathrm{~lx}$ recommendation. The highest mean illuminance level was calculated at Onisifor Ghibu College - 625 lx, which is the result of implementing new state of the art LED technology. Uniformity in all educational buildings is below the 0.6 ratio, revealing uneven light distribution. The colour correlated temperature of the light sources has a wide variation, from $3000 \mathrm{~K}-10000 \mathrm{~K}$, indicating that there are no clear instructions on how to choose this light source feature. Colour rendering index of the luminaires is mostly below the $80 \mathrm{Ra}$ values recommended by the norm. This campaign's audit can be useful for the public authorities in order to have a clear situation of the existing lighting systems and about improvement possibilities in future refurbishment projects.
\end{abstract}

Key words: school, lighting, campaign, illuminance

\section{Introduction}

As many municipalities are willing to replace existing, fluorescent lighting with new LED solutions, it is important to perform a survey of existing lighting characteristics to see if they are in line with the norms in place and to see if new ones perform better. Adequate and appropriate lighting enables pupils and students to perform visual tasks efficiently and accurately. The degree of visibility and comfort required in educational buildings have a central role for comfort and well-being, 
regardless of the type of activity and duration. Therefore, it is important to evaluate the educational buildings across Romania, to determine whether the lighting conditions are met with the existing lighting systems.

There are many methods of how to evaluate the lighting system in a building, such as the analytic hierarchy method used by Leccese, F. et al. [1] which reveals that adequate lighting levels in a classroom are dependent on other factors aside for the illuminance levels on the main task areas, such as luminance distribution, glare, daylight availability, flicker and circadian effects. The results exposed inadequate lighting solutions, compared to the current trends. Bellia, Laura, et al. [2] have demonstrated that HDR imaging technology can be a useful tool in order to evaluate the EN 12464-1:2011 requirements and other lighting parameters which are relevant for the users' eye, at a school in Naples, Italy. According to Motta Cabrera and Zareipour [3], there is a possibility to achieve energy savings up to $70 \%$, if lighting waste patterns are identified and avoided, in typical classrooms across Canada, by using data association mining. This tool can be used to determine association rules and understand these waste patterns. Rucinska and Trzaski [4] have concluded that it is necessary to consider the efficiency of the lighting systems during the buildings design process, as well as the suitable window parameters, which will have an impact on the energy balance, due to the high share of lighting demand in schools. Lighting control systems are also a key parameter in achieving energy savings, by mixing daylight and electric light in indoor spaces. Kaminska and Ozadowicz [5] have shown that there is a possibility to further reduce the energy consumption by $24 \%$ on educational buildings in Poland, by using complex KNX-based automation systems and taking daylight into account. Lassandro, Paula, et al. [6] developed a tool in the form of a virtual tour that can aid the decision-making process for retrofitting solutions in schools, correlated with students' post-occupancy evaluation surveys. Dascalaki, Elena G. and Vasileios G. Sermpetzoglou [7] have analyzed the energy performance of 135 Hellenic schools and revealed that using lighting control systems and energy efficient lighting fixtures would reduce energy waste and contribute to the reduction of energy demand. Another study from Doulos, L.T. et al. [8] made in schools from Greece, highlighted the importance of combining high efficiency luminaires with daylight controls to fulfill near Zero Energy Buildings (nZEB) requirements for educational buildings. This could also be applied in Romania, due to the operation time during daytime, when there is an abundance of natural light. S. A. Ghita and T. Catalina [9] made an IEQ assessment of 3 schools in Valcea County, where it was found that the illumination level was below the recommendations of the SR EN-12464:2011 [10] for indoor workplaces, with a range between 44 lx as the lowest mean illumination level and $281 \mathrm{~lx}$ as the highest mean illumination level. Another IEQ study of 5 classrooms for students diagnosed with learning challenges and attention disorder in the Slovak Republic made by Vilcekova, S., et al. [11] revealed that the illumination levels were low and caused visual discomfort. Energy reduction can be achieved by using smart lighting control systems, such as the one proposed by de Rubeis, T., et al. [12] with a wireless communication protocol. Such a control system can reduce the energy consumption by almost $70 \%$ and has a lower payback period when compared to existing control systems on the market. Castilla, N., et al. [13] focused their 
study on students' subjective assessment of the university classrooms and the results showed a clear connection between light and space. It is important to place students and teachers in the center of the lighting design process.

Most educational buildings in Romania were constructed before 1990 and since then, the lighting recommendations have changed as technology evolved. Nowadays, there is a steady direction towards energy efficient public buildings and the educational sector will have an impact in the process. Before the use of European norm SR EN12464:2011 there was the Romanian norm STAS 6646 [14] (first version in 1966 and the next one in 1987) and the Romanian regulation PE 136/1988 [15]. For example, the illuminance level in classrooms was $300 \mathrm{~lx}$ at a height between $0.85-1 \mathrm{~m}$ from the floor, on a horizontal plane. In 1966, the illuminance recommendations of Romanian standard 6646 were depending on the type of lamps: lower levels for incandescent lamps and higher levels for fluorescent lamps. For administrative offices, a local supplementary lighting was necessary, in the form of a table lamp. From Table 1 we can see that there was a difference in the recommended values depending on the lamps and these values are lower than those in SR-EN 12464.

Table 1

Recommended values according to Romanian norm STAS 6646-66 (valid until 1987) for schools, high-schools, universities and research institutes

\begin{tabular}{|c|c|c|c|}
\hline \multirow{2}{*}{ Room } & \multicolumn{2}{|c|}{ Illuminance value } & \multirow{2}{*}{$\begin{array}{c}\text { Height of the } \\
\text { task area }\end{array}$} \\
\cline { 2 - 4 } & Fluorescent lamps & Incandescent lamps & 75 \\
\hline Professors office, secretary & 200 & 100 & $0.85-1 \mathrm{~m}$ \\
\hline Classes, lecture halls & 300 & 150 & $0.85-1 \mathrm{~m}$ \\
\hline Laboratory & 300 & 200 & $0.85-1 \mathrm{~m}$ \\
\hline Drawing and art classes & 400 & 150 & $0.85-1 \mathrm{~m}$ \\
\hline Libraries & 300 & 75 & $0.85-1 \mathrm{~m}$ \\
\hline Administrative offices $(\mathrm{x})$ & 200 & 75 & 0 \\
\hline Sport halls & 200 & 75 & 0 \\
\hline Staircases and corridors & 200 & & \\
\hline
\end{tabular}

Uniformity for civil buildings was supposed to be 0.5 and for passageways, corridors and staircases 0.25 . Emergency lighting was not compulsory for schools, only for rooms with more than 100 people (lecture halls) and for passageways and staircases used by more than 50 people (all the schools and universities). Illuminance level for emergency lighting was supposed to be 0.2 1x. In 1988, a new recommendation was set with the Romanian normative PE136/1988 with a single recommended illuminance level, regardless of the type of lamp, as displayed in Table 2. 
Alexandru-Daniel Vlas, Andy-Alexandru Balazs, Andras Vernes, Dorin Beu, Mircea-Ion Buzdugan

Table 2

Recommended values according to PE 135/1988 for schools, high-schools, universities and research institutes

\begin{tabular}{|c|c|c|}
\hline Room & Illuminance value & $\begin{array}{c}\text { Height of the task } \\
\text { area }\end{array}$ \\
\hline Professors office, secretary & 150 & $0.85-1 \mathrm{~m}$ \\
\hline Classes, lecture halls & 300 & $0.85-1 \mathrm{~m}$ \\
\hline Blackboards & 300 & $\begin{array}{c}1.5 \mathrm{~m} \text { on vertical } \\
\text { surface }\end{array}$ \\
\hline Laboratory & 300 & $0.85-1 \mathrm{~m}$ \\
\hline Drawing and art classes & 400 & $0.85-1 \mathrm{~m}$ \\
\hline Libraries & 300 & $0.85-1 \mathrm{~m}$ \\
\hline Administrative offices & 150 & $0.85-1 \mathrm{~m}$ \\
\hline Sport halls & 100 & 0 \\
\hline Staircases and corridors & 50 & 0 \\
\hline
\end{tabular}

Comparing Table 1 and 2, it can be observed that the recommended values for fluorescent light sources were lowered in 1988 for some spaces (professors and administrative offices, sports halls, staircases and corridors), as a consequence of energy rationalization in all spaces. Also in Table 2, the illuminance level for blackboards is introduced, for the first time. This is an indication of increased lighting quality in the classrooms, by combining the horizontal illuminance with the vertical blackboard plane.

In this campaign, a direct method of evaluating lighting systems and how it affects the spatial illuminance, colour-correlated-temperature and uniformity has been developed. It is based on the illuminance measurements in the classroom, using a portable light spectrometer. Compared to other methods, it has the benefit of obtaining results from a calibrated tool, developed particularly for lighting applications. Other methods such as the ones who use HDR images can also be useful, but there is a possibility to have wide deviations, due to potentially unbalanced calibrations. Furthermore, it is our goal to examine classrooms with electric light only.

The campaign will help to create a database of lighting conditions in classrooms, as exemplified in Table 4, by taking precise measurements in the majority of the educational buildings across Romania. Furthermore, we can obtain a pattern of illuminance levels, which are useful in order to understand what solution is required in each type of classroom. The preliminary results of the measurement campaign indicate that the illuminance level in the Technical University of Cluj-Napoca's classrooms is approximately $37.72 \%$ less than the recommended value of $500 \mathrm{~lx}$. In the case of the 
Educational Buildings in Romania - Survey of Existing Lighting Systems

examined schools, the level varies between $4.21 \%$ and $59.89 \%$ below the reference value of $300 \mathrm{~lx}$. There are 3 classrooms with values higher than the reference value at Onisifor Ghibu, Mihai Eminescu and Nicolae Balcescu College, with 625 lx, 359 lx and $329 \mathrm{~lx}$. The uniformity ratio is also below the value of 0.6 , in the majority of the cases. As for the colour rendering index, the results indicate that half of the investigated spaces have a value above $80 \mathrm{Ra}$.

The structure of the paper after introduction contains the detailed description of the method, then it continues with a presentation of the results. Moreover, there is a conclusion section based on the results and observations obtained from the examined spaces. Finally, the future work section is describing the following steps in order to have a complete evaluation and proposed lighting solution.

\section{Method}

The measurement method has been applied in several high schools from Brasov and Cluj-Napoca (Andrei Saguna College, Unirea College and Johannes Honterus College - Brasov, Anghel Saligny College, Energetic College, Mihai Eminescu College, Nicolae Balcescu College, Onisifor Ghibu College - Cluj-Napoca). The Faculty of Building Services Engineering in Cluj-Napoca, was also part of the campaign. The measurement method used is based on the application of the calculation formula for lighting levels, from the SR EN 12464-1[9] standard, by generating a grid with points of interest, and then to determine by means of a portable light spectrometer, the lighting level for each of these points. The focus of the measurements in each of the educational institutions is in classrooms and gyms. The requirements of the existing lighting standard for indoor workplaces are detailed in Table 3.

Table 3

Types of Activity in Educational Buildings and lighting parameters according to SR-EN 12464-

$1: 2011$

\begin{tabular}{|c|c|c|c|c|}
\hline Room Type & Em [1x] & U0 & $\mathrm{Ra}$ & Specific Requirements \\
\hline $\begin{array}{c}\text { Classrooms for primary } \\
\text { and secondary courses }\end{array}$ & 300 & 0.6 & 80 & Lighting should be controllable \\
\hline $\begin{array}{c}\text { Classrooms for evening } \\
\text { courses and adult } \\
\text { education }\end{array}$ & 500 & 0.6 & 80 & Lighting should be controllable \\
\hline Gyms (general use) & 300 & 0.6 & 80 & $\begin{array}{c}\text { EN 12193 has to be followed for } \\
\text { specific training conditions }\end{array}$ \\
\hline
\end{tabular}

After defining the types of activities in each room examined within the educational institutions, the information obtained will be centralized in a table and will be compared with the parameters recommended by the SR EN 12464-1:2011 standard. 
To determine the illuminance level in the examined spaces, a calculation tool was developed, starting from the SR-EN 12464-1:2011 recommendations of defining a measuring grid. All the relevant parameters which contribute to the final definition of the grid are exemplified in Fig.1.

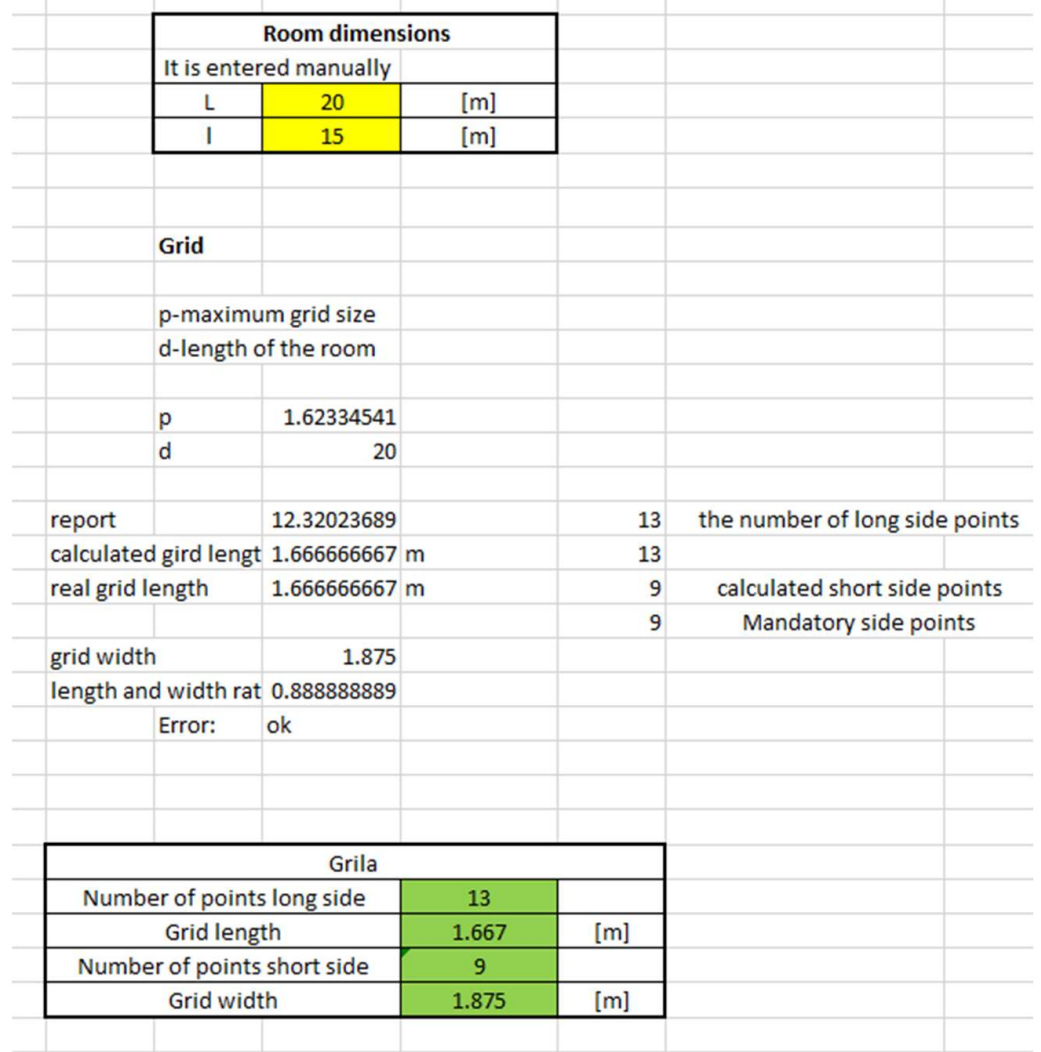

Fig. 1. Grid calculation parameters.

It is also important to know the dimensions of the space, which must be introduced manually. The calculation tool generates a virtual grid which covers the entire space, distributing the points of interest on both the length and width of the room. The calculation tool generates a virtual grid which covers the entire space, distributing the points of interest on both the length and width of the room. An example of a calculated grid is shown in Fig.2, which shows the length of the grid as columns and the width of the grid as rows.

The measuring points indicated by the calculation tool will be marked in space. Usually, the measurements should be performed in empty space, but in our case, all the classrooms were filled with furniture and other items. Due to the fixed position of the benches, the positions have to be adapted to the existing conditions and it may have an impact on the results. Finally, the portable light spectrometer is placed on a tripod, at the required height, depending on the workplane requirements. In our case, the measuring device was fixed at $0.8 \mathrm{~m}$ from the ground in all classrooms and at ground level for the gym. All the measured results were recorded and filled-in the calculation 
Educational Buildings in Romania - Survey of Existing Lighting Systems

\begin{tabular}{|c|c|c|c|c|c|c|c|c|c|c|c|}
\hline & & & Door & & & & & & & & \\
\hline Masuratori & Column 1 & $\mathrm{C} 2$ & C 3 & C 4 & C 5 & C 6 & C 7 & $\mathrm{C} 8$ & C 9 & C 10 & C 11 \\
\hline iluminare & \begin{tabular}{|l|}
{$[\mathrm{I}]$} \\
\end{tabular} & {$[\mathrm{Ix}]$} & {$[\mathrm{Ix}]$} & {$[\mathrm{Ix}]$} & {$[\mathrm{Ix}]$} & {$[\mathrm{Ix}]$} & {$[\mathrm{Ix}]$} & {$[\mathrm{Ix}]$} & {$[\mathrm{Ix}]$} & {$[\mathrm{Ix}]$} & {$[\mathrm{Ix}]$} \\
\hline Row 1 & 29.86 & 120.93 & 86.56 & 153.35 & 167.6 & 160.5 & 157.48 & 136.73 & 129.44 & 116.13 & 68.42 \\
\hline Row 2 & 216 & 185.71 & 188.65 & 190.69 & 194.35 & 198.65 & 202.24 & 188.63 & 183.53 & 151.28 & 104.79 \\
\hline Row 3 & 359.45 & 210.29 & 149.66 & 126.91 & 149.6 & 126.82 & 141.67 & 113.82 & 118.23 & 103.49 & 79.66 \\
\hline Row 4 & 144.39 & 238.08 & 208.83 & 208.99 & 196.51 & 204.76 & 209.09 & 191.1 & 182.83 & 181.31 & 100.46 \\
\hline Row 5 & 109.18 & 236.8 & 224.93 & 244.82 & 286.5 & 276.5 & 299.87 & 265.63 & 235.46 & 157.11 & 74.4 \\
\hline Row 6 & 118.87 & 197.95 & 215.27 & 227.34 & 248.87 & 283.2 & 319.29 & 316.66 & 260.52 & 192.6 & 131 \\
\hline Row 7 & 106.13 & 174.56 & 189.91 & 195.28 & 208.19 & 251.77 & 279.89 & 262.22 & 249.55 & 202.47 & 142.34 \\
\hline Row 8 & 117.65 & 139.92 & 157.02 & 184.32 & 186.42 & 224.25 & 261.92 & 212.71 & 215.93 & 176.33 & 138.34 \\
\hline Row 9 & 45.45 & 114.48 & 143.81 & 142.72 & 151.07 & 188.27 & 179.22 & 176.46 & 144.47 & 114.25 & 94.53 \\
\hline & Window & & Window & & & Window & & & Window & & \\
\hline
\end{tabular}

Fig. 2. Example of a generated grid with results.

tool. Then, in order to determine the average illuminance in each space, we applied the arithmetic mean of all measured points. The uniformity is also calculated based on the ratio between the minimum measured value and the calculated average value.

The measurements were done using a GL SPECTIS 1.0 Touch + Flicker [16]. This portable light spectrometer, as displayed in Fig. 3 can be used to evaluate various colorimetric and photometric parameters, such as color-correlated temperature of the light source, the color rendering index, the illuminance value and also the flicker level of an existing lighting installation. It is also possible to compare results from a light source, the color rendering index, the illuminance value and also the flicker level of an existing lighting installation. It is also possible to compare results from a lighting calculation from software such as DIALux Evo [17] or similar, with the existing parameters, after the lighting systems implementation. It is also possible to generate comprehensive lighting reports that can be used for the lighting industry and even for the end users.

\section{Results}

In this chapter, the measurement results are presented. The lighting parameters, either measured or calculated in the areas of interest, depending on the type of activity will be centralized and will be compared with the minimum values prescribed by the

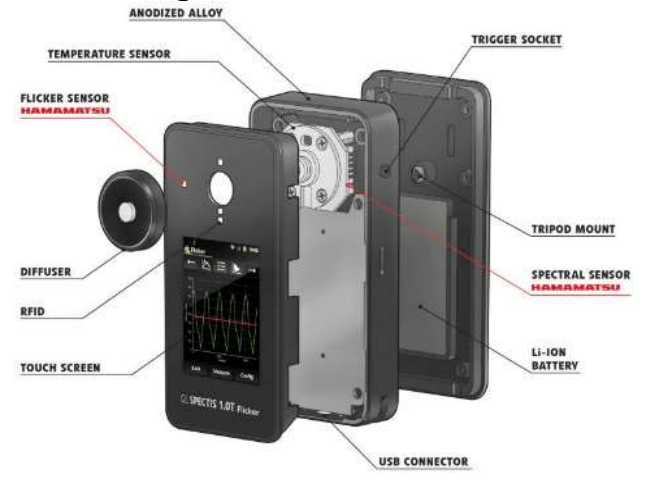

Fig. 3. GL SPECTIS 1.0 Touch + Flicker Spectrometer. 
Alexandru-Daniel Vlas, Andy-Alexandru Balazs, Andras Vernes, Dorin Beu, Mircea-Ion Buzdugan

SR-EN-12464-1:2011 standard. The values in Table 4 represent the existing situation in the educational institutions that were studied.

Table 4

Measured and calculated lighting parameters of the educational spaces

\begin{tabular}{|c|c|c|c|c|c|c|}
\hline School & Room type & Em & U0 & CCT & $\mathrm{Ra}$ & Light Source \\
\hline \multirow{3}{*}{$\begin{array}{l}\text { Andrei Saguna } \\
\text { College - Brasov }\end{array}$} & Class-01 & 179.58 & 0.166 & 5182 & 77.1 & T8 FL \\
\hline & Class-02 & 243.2 & 0.333 & 3464 & 85.1 & T8 FL \\
\hline & Class-03 & 188.66 & 0.212 & 5457 & 71.4 & T8 FL \\
\hline \multirow{2}{*}{$\begin{array}{c}\text { Unirea College - } \\
\text { Brasov }\end{array}$} & Class-01 & 121.5 & 0.096 & 9514 & 82.1 & T8 FL \\
\hline & Class-02 & 119.18 & 0.306 & 10088 & 82.1 & T8 FL \\
\hline \multirow{4}{*}{$\begin{array}{c}\text { Johannes Honterus } \\
\text { College - Brasov }\end{array}$} & Class-01 & 251 & 0.361 & 5869 & 73.3 & T8 FL \\
\hline & Class-02 & 168.32 & 0.372 & 6047 & 74.9 & T8 FL \\
\hline & Class-03 & 180.24 & 0.258 & 5594 & 72.3 & T8 FL \\
\hline & Class-04 & 549.99 & 0.294 & 3581 & 81.4 & T5 FL \\
\hline \multirow{6}{*}{$\begin{array}{c}\text { Faculty of Building } \\
\text { Services UTCN - } \\
\text { Cluj-Napoca }\end{array}$} & Class-01 & 413.45 & 0.611 & 3703 & 83.4 & T8 FL \\
\hline & Class-02 & 250.1 & 0.52 & 5595 & 72.1 & T8 FL \\
\hline & Class-03 & 316.78 & 0.48 & 3467 & 81.4 & T8 FL \\
\hline & Class-04 & 328.25 & 0.415 & 3582 & 82.7 & T8 FL \\
\hline & Class-05 & 350.95 & 0.537 & 5576 & 72.4 & T8 FL \\
\hline & Class-06 & 208.88 & 0.394 & 5599 & 71.8 & T8 FL \\
\hline $\begin{array}{l}\text { Anghel Saligny } \\
\text { College - Cluj- } \\
\text { Napoca }\end{array}$ & Class-01 & 234.41 & 0.415 & 5092 & 75.2 & T8 FL \\
\hline \multirow{2}{*}{$\begin{array}{c}\text { Energetic College - } \\
\text { Cluj-Napoca }\end{array}$} & Class-01 & 247.32 & 0.457 & 4068 & 79.56 & T8 FL \\
\hline & Class-02 & 314.71 & 0.238 & 3784 & 81.3 & LED \\
\hline $\begin{array}{l}\text { Mihai Eminescu } \\
\text { College - Cluj- } \\
\text { Napoca }\end{array}$ & Class-01 & 359.3 & 0.404 & 4789 & 80.7 & LED \\
\hline $\begin{array}{l}\text { Nicolae Balcescu } \\
\text { College - Cluj- } \\
\text { Napoca }\end{array}$ & Class-02 & 329.43 & 0.506 & 3654 & 78.1 & T5 FL \\
\hline
\end{tabular}


Educational Buildings in Romania - Survey of Existing Lighting Systems

\begin{tabular}{|c|c|c|c|c|c|c|}
\hline School & Room type & Em & U0 & CCT & Ra & Light Source \\
\hline $\begin{array}{c}\text { Onisifor Ghibu } \\
\text { College -Cluj- } \\
\text { Napoca }\end{array}$ & Class-01 & 625.56 & 0.297 & 3370 & 83 & LED \\
\hline
\end{tabular}

When reporting to reference values in the standard, it can be observed that not all the measured or calculated parameters in the classrooms are simultaneously fulfilled, as displayed in Table 5. The illumination level in the classrooms of the 8 studied schools meets the recommendations in the proportion of $40.11 \%$ in the most unfavourable case (Unirea College - Brasov), and the most favourable case at Onisifor Ghibu with a value of $625.56 \mathrm{~lx}$ which is more than double of the recommended level. In the university classrooms' case, the illuminance level is fulfilled at an average of $62.28 \%$. In the case of uniformities, there are major differences from the most favorable case (Nicolae Balcescu College - Cluj-Napoca) in the proportion of $85 \%$ and the least favorable college located at $33.50 \%$ (Unirea College-Brasov).

Table 5

Comparison of Lighting levels, uniformity and colour rendering index in studied classrooms

\begin{tabular}{|c|c|c|c|c|c|}
\hline $\begin{array}{c}\text { Educational } \\
\text { Building }\end{array}$ & Avg Em (lx) & $\begin{array}{c}\text { Em/Enorm } \\
(\%)\end{array}$ & Avg U0 & $\begin{array}{c}\text { U0/ U0 } \\
\text { norm (\%) }\end{array}$ & Avg CRI \\
\hline $\begin{array}{c}\text { Andrei Saguna } \\
\text { College - Brașov }\end{array}$ & 203.81 & $67.93 \%$ & 0.237 & $39.50 \%$ & 77.87 \\
\hline $\begin{array}{c}\text { Unirea College - } \\
\text { Brașov }\end{array}$ & 120.34 & $40.11 \%$ & 0.201 & $33.50 \%$ & 82.10 \\
\hline $\begin{array}{c}\text { Johannes Honterus } \\
\text { College - Brașov }\end{array}$ & 287.39 & $95.79 \%$ & 0.321 & $53.54 \%$ & 75.48 \\
\hline $\begin{array}{c}\text { Faculty of Building } \\
\text { Services UTCN - } \\
\text { Cluj-Napoca }\end{array}$ & 311.40 & $62.28 \%$ & 0.492 & $82.13 \%$ & 77.30 \\
\hline $\begin{array}{c}\text { Anghel Saligny } \\
\text { College-Cluj- } \\
\text { Napoca }\end{array}$ & 234.41 & $79 \%$ & 0.415 & $70 \%$ & 70.26 \\
\hline $\begin{array}{c}\text { Energetic College- } \\
\text { Cluj-Napoca }\end{array}$ & 281.01 & $94 \%$ & 0.352 & $59 \%$ & 76.34 \\
\hline $\begin{array}{c}\text { Mihai Eminescu } \\
\text { College-Cluj- } \\
\text { Napoca }\end{array}$ & 359.3 & $120 \%$ & 0.404 & $68 \%$ & 72.44 \\
\hline
\end{tabular}


Alexandru-Daniel Vlas, Andy-Alexandru Balazs, Andras Vernes, Dorin Beu, Mircea-Ion Buzdugan

\begin{tabular}{|c|c|c|c|c|c|}
\hline $\begin{array}{c}\text { Nicolae Bălcescu } \\
\text { College-Cluj- } \\
\text { Napoca }\end{array}$ & 329.43 & $110 \%$ & 0.506 & $85 \%$ & 78.1 \\
\hline $\begin{array}{c}\text { Onisifor Ghibu } \\
\text { College-Cluj- } \\
\text { Napoca }\end{array}$ & 625.56 & $209 \%$ & 0.297 & $50 \%$ & 83 \\
\hline
\end{tabular}

Abbreviations in Table 4 and 5 - Em (mean illuminance); Avg Em (average mean illuminance per schoom); lx (lux); Enorm (reference illuminance); U0 (uniformity); U0norm (reference uniformity); Avg CRI (average colour rendering index); CCT (colour correlated temperature); Ra (colour rendering index); T8/T5 FL (T8/T5 fluorescent tube); LED (light emitting diode).

\section{Conclusions}

The lighting parameters measured in the educational buildings across Romania are below the requirements of the SR EN 12464-1:2011 for indoor workplaces. The majority of the university classrooms have a lower illuminance level, 37.72\% less than the recommended level of $500 \mathrm{~lx}$. After analysing the illuminance levels in school classrooms in Brasov, the average results are 32.07\% (Andrei Saguna College), 59.89\% (Unirea College) and 4.21\% (Johannes Honterus College) less than the reference value of 300 lx. For Cluj-Napoca, the results are either below the reference value (Anghel Saligny College - 21\%; Energetic College Class $01-17 \%$ ) or above (Energetic College Class 02, Mihai Eminescu College, Nicolae Balcescu College and Onisifor Ghibu College). Furthermore, in all cases, the uniformity ratio is situated below the mean value of 0.6 , indicating that the overall illuminance distribution is uneven. Regarding the Colour Correlated Temperature, there is a wide variation of values from 3000 to 10000 $\mathrm{K}$. This variation is a clear indication that there are no clear instructions on how to choose the lighting source. Regarding the lighting control systems, in the educational institutions of this campaign, there were On/Off type switches installed, with the only exception at Onisifor Ghibu College, which has implemented a lighting control system capable of dimming the luminaires according to daylight availability, movement and presence sensors. Using dedicated lighting control systems and energy efficient luminaires could significantly increase the quality of the visual comfort and reduce energy consumption.

The results obtained from this measurement campaign will be used to create a expand a database of existing lighting conditions in classrooms, having the illuminance levels, uniformity and colour rendering index measurements in the majority of the educational buildings across Romania. With these results, we can generate a pattern that covers the electric lighting conditions in each type of classroom, which will further help the process of designing a new lighting solution. It is also useful for the public authorities as an updated information database regarding the status of the existing lighting systems. 
Educational Buildings in Romania - Survey of Existing Lighting Systems

\section{Future Work}

We aim to collect further relevant data about the lighting systems in educational buildings across Romania in order to have a deeper database of the existing situation. Moreover, we aim to develop a lighting proposal that will meet the recommendations of the lighting standard, provide visual comfort and reduce the energy consumption. It would also serve as a guide for the public authorities in the decision-making process, before opting to implement new lighting solutions.

\section{References}

[1] Leccese, F., et al. "A Method to Assess Lighting Quality in Educational Rooms Using Analytic Hierarchy Process." Building and Environment, vol. 168, Jan. 2020, p. 106501. DOI.org (Crossref), doi:10.1016/j.buildenv.2019.106501.

[2] Bellia, Laura, et al. "Methods to Evaluate Lighting Quality in Educational Environments." Energy Procedia, vol. 78, Nov. 2015, pp. 3138-43. DOI.org (Crossref), doi:10.1016/j.egypro.2015.11.770.

[3] Motta Cabrera, David F., and Hamidreza Zareipour. "Data Association Mining for Identifying Lighting Energy Waste Patterns in Educational Institutes.” Energy and Buildings, vol. 62, July 2013, pp. 210-16. DOI.org (Crossref), doi:10.1016/j.enbuild.2013.02.049.

[4] Rucińska, Joanna, and Adrian Trząski. "Measurements and Simulation Study of Daylight Availability and Its Impact on the Heating, Cooling and Lighting Energy Demand in an Educational Building." Energies, vol. 13, no. 10, May 2020, p. 2555. DOI.org (Crossref), doi:10.3390/en13102555.

[5] Kaminska, Aniela, and Andrzej Ożadowicz. "Lighting Control Including Daylight and Energy Efficiency Improvements Analysis.” Energies, vol. 11, no. 8, Aug. 2018, p. 2166. DOI.org (Crossref), doi:10.3390/en11082166.

[6] Lassandro, Paola, et al. "School Building Heritage: Energy Efficiency, Thermal and Lighting Comfort Evaluation Via Virtual Tour." Energy Procedia, vol. 78, Nov. 2015, pp. 3168-73. DOI.org (Crossref), doi:10.1016/j.egypro.2015.11.775.

[7] Dascalaki, Elena G., and Vasileios G. Sermpetzoglou. "Energy Performance and Indoor Environmental Quality in Hellenic Schools." Energy and Buildings, vol. 43, no. 2-3, Feb. 2011, pp. 718-27. DOI.org (Crossref), doi:10.1016/j.enbuild.2010.11.017.

[8] Doulos, L. T., et al. "Minimizing Energy Consumption for Artificial Lighting in a Typical Classroom of a Hellenic Public School Aiming for near Zero Energy Building Using LED DC Luminaires and Daylight Harvesting Systems." Energy and Buildings, vol. 194, July 2019, pp. 201-17. DOI.org (Crossref), doi:10.1016/j.enbuild.2019.04.033.

[9] S. A. Ghita and T. Catalina, "Energy efficiency versus indoor environmental quality in different Romanian countryside schools," Energy and Buildings, vol. 92, pp. 140-154, Apr. 2015, doi: 10.1016/j.enbuild.2015.01.049.

[10] SR EN 12464-1/2011 Lumina si iluminat. Iluminatul locurilor de munca. Partea 1: Locuri de munca interioare (Light and lighting. Lighting of workplaces. Part 1: Indoor work places).

[11] S. Vilcekova, L. Meciarova, E. K. Burdova, J. Katunska, D. Kosicanova, and S. Doroudiani, "Indoor environmental quality of classrooms and occupants' comfort in a special education school in Slovak Republic," Building and Environment, vol. 120, pp. 29-40, Aug. 2017, doi: 10.1016/j.buildenv.2017.05.001.

[12] T. de Rubeis et al., "A first approach to universal daylight and occupancy control system for any lamps: Simulated case in an academic classroom," Energy and Buildings, vol. 152, pp. 24-39, Oct. 2017, doi: 10.1016/j.enbuild.2017.07.025. 
Alexandru-Daniel Vlas, Andy-Alexandru Balazs, Andras Vernes, Dorin Beu, Mircea-Ion Buzdugan

[13] N. Castilla, C. Llinares, J. M. Bravo, and V. Blanca, "Subjective assessment of university classroom environment," Building and Environment, vol. 122, pp. 72-81, Sep. 2017, doi: 10.1016/j.buildenv.2017.06.004.

[14] STAS 6646-66 Iluminatul artificial. Conditii generale pentru iluminatul in constructii civile si industriale (Artificial lighting - General conditions for lighting in civil and industrial buildings).

[15] PE 136/1988 Normativ republican privind utilizarea rationala a energiei electrice la proiectarea si exploatarea instalatiilor de iluminat artificial si utilizari casnice (Republican regulation for the rational use of electric energy for the design and use of the artificial lighting installations and residential use).

[16] "Spectis 1.0 Touch + Flicker." GL Optic | Light Quality Control, https://gloptic.com/products/glspectis-1-0t-flicker/. Accessed 30 Mar. 2021.

[17] GmbH, DIAL. "DIALux." DIAL GmbH, https://www.dial.de/en/dialux/. Accessed 30 Mar. 2021. 